\title{
Kansainvälistyminen ja aikuiskoulutus
}

Motto: Ajattele globaalisti, toimi paikallisesti, siis koska tunnen vastuuta koko ihmiskunnasta, tankkaan päähäni saksan vahvat verbit.

\section{Kansainvälinen perinne}

Vahva kansallisuusaate on ollut Suomen kansansivistystyön synnyn kulmakiviä. Tämä ei kuitenkaan estänyt sitä, että alusta saakka työlle haettiin ja saatiin malleja rajojemme ulkopuolelta. Muistettakoon vain nyt niin perinsuomalaisia aikuiskasvatuksen muotoja kuin kansanopisto, jonka malli haettiin Tanskasta tai opistokerhotoiminnasta, jonka juuria löytyy aina Atlantin takaa.

Kansansivistyksen pioneerit olivat yleensäkin innokkaita pitämään yllä kansainvälisiä suhteita ja hakemaan vaikutteita ulkomailta. Joskus vaikuttaa siltä, että aikuiskasvattajien pitkäaikaiset vierailut muitten maiden aikuiskasvatuslaitoksissa ovat jopa suhteellisesti vähentyneet noista alkuajoista, vaikka ulkoiset mahdollisuudet ovatkin lisääntyneet. Tällaisten henkilökohtaisten oleskelujaksojen sijaan ovat tulleet muut informaatiovaihtoehtotavat, "virallinen" yhteydenpito edunvalvojaorganisaatioiden tai viranomaisten kautta taikka turistimaiset ryhmämatkailut sekalaisiin kohteisiin.

\section{Nykyinen kansainvälinen yhteistyö}

\section{Pohjoismainen yhteistyö}

Aikojen alusta kansainvälinen yhteistyömme on ensisijaisesti ollut pohjoismaista yhteistyötä. Pohjoismaiden ministerineuvoston piirissä järjestäytyneellä koulu- ja yliopistoyhteistyöllä on pitkät perinteet. Aikuiskoulutus on päässyt mukaan vähitellen ja vasta aivan viime vuosina se on saanut oman kiinteän budjettiosuutensa neuvoston työssä. Sen mukaan se on saanut myös pysyvän aikuiskoulutuksen pohjoismaisen johtoryhmän, joka uudessa kokoonpanossaan on juuri aloittanut nelivuotiskautensa.

Voi kuitenkin ennustaa, että pohjoismaisen yhteyden merkitys vähenee laajempien yhteistyömahdollisuuksien edetessä.

\section{Euroopan Neuvosto}

Vaikka Suomi vasta nyt uskaltaa liittyä Euroopan Neuvostoon, on se jo vuodesta 1970 ollut mukana EN:n jäsenmaiden Euroopan kulttuuriyleissopimuksessa. Sen piirissä aikuiskoulutus on ollut $n$. 10 vuotta näkyvästi mukana. Viime vuonna aloitettin jäsenmaissa toinen laaja aikuiskoulutusverkostoprojekti, jossa Suomen osalta on mukana Lapin aikuiskoulutuskokeilu (LAIKO).

\section{OECD}

Taloudellisen yhteistyön ja kehityksen järjestö OECD on asettanut opetustoimen komitean, jossa erityisesti ammatillisen aikuiskoulutuksen asiat ovat viime vuosina (viimeksi viime kevään kokouksessa) tulleet vahvasti esille.

Järjestö suorittaa silloin tällöin myös jäsenmaiden koulutuspolitiikan perusteellisen arvioinnin. Muutama vuosi sitten tällainen tutkimuskomissio kävi arvioimassa Suomen koulutusta. Loppukritiikissä Pariisissa aikuiskoulutuksemme suoriutui hyvin arvosanoin.

\section{Unesco}

Unesco on kansainvälisistä järjestöistä ollut ehkä aktiivisin aikuiskoulutuksen alueella. Sehän laati jo vuonna 1976 oman aikuiskoulutussuosituksensa ja piti vuonna 1985 jo neljännen aikuiskoulutuksen maailmankonferenssinsa. Unescon aikuiskoulutuspolitiikkaan lyö vahvan leiman järjestön luonteen mukaisesti kehitysmaiden tarpeet ja vaatimukset.

\section{Epävirallinen yhteistyö}

Aikuiskoulutusjärjestöillä niinkuin yksityisillä aikuiskouluttajilla on luonnollisesti monenlaisia kiinteämpiä ja löysempiä kansainvälisen yhteistyön muotoja. Merkityksellisimmät lienevät Vapaan sivistystyön yhteisjärjestön ylläpitämät yhteydet Euroopan aikuiskasvatustoimistoon ja Kansainväliseen aikuiskasvatusliittoon. Perinteitä on myuös osallistumisella Manchester Collegen ja Genevekoulun toimintaan.

Erikseen on mainittava lähinnä valtuuskuntien vaihdon muodossa tapahtuva yhteydenpito useisiin itäblokin maihin. 


\section{Kansainvälisyys ei ole vain Euroopan talous}

Euroopan yhdentyminen on juuri nyt muotislangia. Sen ohella on muistettava kaikki muut yhteytemme ja ennen kaikkea kehitysmaat. Jälkimmäisten tilannetta ajatellen aikuiskoulutusongelmamme kaiken kaikkiaan ovat eliitin kvasiongelmia. Kehitysmaissa Suomen aikuiskoulutuksella olisi yhteisvoimin varsinaisten Suomen ja kansainvälisten kehitysyhteistyöorganisaatioiden kanssa suunnaton työkenttä.

Siinä eivät kuitenkaan auta kertakeräykset tai hetken innostus. Tarvitaan todella pitkäjänteistä suunnittelua ja yhteityötä vastaanottajien kanssa. YK:n kehitysyhteistyössä avoinna olevien toimien luettelon seuraaminen antaa käsityksen, mitkä mahdollisuudet Suomen aikuiskasvattajilla maailmalla olisivat.

\section{Uudet kansainvälistymishaasteet}

Nyt koko yhteiskuntamme on totaalisesti astumassa osaksi yhtenäistyvää maailmaa. Aikuiskasvatus on tunnetusti tuomittu kukoistamaan tai kuihtumaan sen mukaan, miten se pystyy aistimaan ja ottamaan huomioon ilmassa liikkuvia muutoksia.

On korkea aika paneutua analysoimaan uutta kansanvälistymistä ja pohtia sen seurauksia aikuiskoulutukselle. Liian helpolla aikovat päästä ne, jotka päättävät lisätä kielten osuutta, perustaa uuden kansainvälisyyspiirin tai osallistua uuteen pakanamaaprojektiin. Ei myöskään auta piiloutua sen harhan taakse, että kansainvälistyminen on lähinnä matkailua ja kauppaa, tai että kyllä viranomaiset sen hoitavat.

\section{Suomen uusi asema}

Sanotaan, että uusi kansanivälistyminen, johon teknologinen kehitys antaa mahdollisuuden, antaa pienille maille kuten Suomelle aivan uusia mahdollisuuksia astua mailmannäyttämölle. Ei kai vain käy päinvastoin?

Yleiskehityshän kulkee suuria yksiköitä suosivaan suuntaan. Suurten valtioiden ja ennen kaikkea ylikansallisten organisaatioiden merkitys maailmassa kasvaa. Ylikansalliset taloudelliset lait ohittavat yhä useammin kansallisen lainsäädännön mahdollisuudet. Myös kulttuurin muutokset ovat yhä vähemmän sisäsyntyisiä ja yhä enemmän tulosta ulkoisista paineista.

Yhä vähemmän maailmaa kiinnostaa Suomen kaltainen pieni maa ja markkina-alue, jonka kummallinen kieli jo sinänsä on este kanssa- ja kaupankäynnille.

Olemme eläneet maailman tietoisuudessa paljolti siltana idän ja lännen välillä. Kiplingin ajatuksia uhmaten kumpikin ilmansuunta on käyttänyt Suomea kohtaamispaikkanaan. Maailmanlaajuisen glasnost-ilmiön mukana siltaasemamme menettää merkitystään. Itä ja länsi alkavat käyttää suorempia ja luonnollisempia kohtaamistapoja.

Yhtäkkiä huomaamme olevamme pieni maa ison naapurin kupeessa, naapurin, joka on avannut monia suurempia näyteikkunoita länteen kuin tämä meidän räppänämme. Suurvallalla on suuret linjat ja intressit. Edessä saattavat olla katkerat sopeutumisen vuodet.

Voimme jonakin päivänä huomata olevamme entistä syrjemmässä Euroopan takapihan hämärässä, johon kansainväliset tuulet löyhähtelevät lähinnä vain ylikansallisten ympäristöhaittojen muodossa.

\section{Näytön paikka}

Tietyllä tavalla olemme tässä kaikessa yhdentymiskehityksessä entistä selvemmin yksin, omien jalkojemme varassa. Meidän on omalla osaamisellamme tehtävä itsemme tärkeiksi taloudellisesti yhdentyvässä mailmassa. Uusi teknologia tarjoaa tähän mahdollisuudet. Se tarjoaa myös aikuisten koulutukseen aivan uusia mahdollisuuksia, joilla voidaan voittaa monet keskeiset koulutuksen tiellä olleet esteet.

Koulumaailma kantaa selviytymisestämme ensisijaisen vastuun, mutta selvästi enstistä suurempi osa vastuusta lankeaa myös aikuiskoulutukselle. Jatkuva koulutus on välttämättömyys.

\section{Jatkuva koulutus}

Työn hinnoittelulla olemme lyöneet itsemme ulos kaikesta sellaisesta työvaltaisesta toiminnasta, jonka tuotteita pystytään kuljettamaan idästä länteen. Ennen pitkää antanemme suuren osan myös omassa maassa tehtävästä suorittavasta työstä siirtolaisten käsiin. Kansainvälinen kilpailu tulee näin epäilemättä laskemaan hintatasoamme, ehkä erityisesti palvelusten hintaa.

Mutta että me saisimme tänne halpoja palveluja, meidän on pystyttävä myös myymään jotakin. Epäilemättä se jokin tulee metsän lisäksi olemaan yhä enemmän erikoistumista ja laatua. Se vaatii yhä pitempää ja yhä lähempää tuotantoa olevaa koulutusta, jota koululaitos ei voi antaa. Samalla aikuiskoulutksemme on hakeuduttava yhä tiiviimpään kansainväliseen yhteistyöhön. 
Kanaviahan meillä aikuiskouluttajille todettiin suureen maailmaan olevan runsaasti. Ongelmana on, miten yhteydet saadaan muutetuksi todelliseksi kansainväliseksi vuorovaikutukseksi.

Voiko näitä edellä kuvattuja kanavia edes pitää oikeina kanavina, joiden kautta Suomen aikuiskoulutus pääsisi tuomaan kansainvälistumisprosessiimme oman panoksensa? Luultavasti ei esimerkiksi liittyminen Euroopan yhteisöön tuo paljonkaan uusia mahdollisuuksia. Resurssimme eivät ensiksikään riitä kaikkien kanavien täyteen hyödyntämiseen.

Toiseksi Euroopan yhteisön aikuiskoulutuspolitiikka on paljon lähempänä sosiaalipolitiikkaa kuin oma ajattelumme. Aikuiskoulutus on Keski-Euroopassa paljon lähempänä lukutaito-opetusta, siirtolaisten sopeuttamista, asumisympäristön sosiaalista kohentamista ja erilaisten vähemmistöryhmien auttamista kuin meillä. Aikuiskasvattajasta tässä mielessä on siellä käytössä aivan oma terminsäkin; animateur.

Uudessa tilanteessa olisi kaikkein ensiksi pohdittava, tuoko geopoliittisesti muuttunut asemamme uusia lähtökohtia aikuiskoulutuspolitiikallemme. Toiseksi olisi päätettävä, lähdemmekö maailmaalle vähittäisinä sopeutujina vai omasta osuudestamme taistelevina leijonina.

Kaikissa tapauksissa olisi ensiksikin pyrittävä saamaan kansainvälistymisen välineet (kielet, tekniikka, atk, viestintäteknologia) mahdollisimman hyvin hallintaan.

Haasteet koskevat koko aikuiskoulutuksen maailmaa. En näe mitään erityistä syytä pitää opiskelulaitosten reviirirajoja kovin jyrkkinä. Tarjontaa on oltava riittävästi ja monipuolisesti. Valtion rahoitus on näihin tarpeisiin usein kovin sidottua ja hitaasti kulkevaa. On oltava mahdollisuus vastata kysyntään heti ja täsmällisesti, varsinkin, jos kysyjä on valmis maksamaan käyvän hinnan.

Aikuiskasvattajan on yhä selvemmin kannettava myös vastuunsa alansa asiantuntijana, joka huomaa erilaiset koulutustarpeet ja kiirehtii tarjoamaan aktiivisesti palveluksiaan. Myös itse aikuiskoulutus tulee enenevässä määrin kansainvälisen kilpailun kentäksi. En pidä suomalaista aikuiskoulutusta lainkaan huonona kauppatavarana maailman markkinoilla.

Kansainvälisyys aikuiskoulutuksessa ei nykyisin ole kokonaisuutena kenenkään hallinnassa. Olisiko sen kehittäminen selkeästi annettava keskitetysti jollekin taholle? Olisiko tällainen taho esimerkiksi opetusministeriön kansainvälisten asiain osasto, Vapaan sivistystyön yhteisjärjestö tai ehkä erillinen kehittämiskeskus? Olisiko samalla muutaman aikuiskou- lutuslaitoksen keskityttävä Viittakiven opiston tapaan kansainvälisiin kysymyksiin? Mistä resurssit?

\section{"Byrokraattien tohinaa, onhan meillä kehitysmaakauppa"}

Edellä esitetyt kysymykset ovat katto-organisaatioiden kysymyksiä, jotka eivät paljon heilauta tavallista aikuista eivät edes aikuiskouluttajaa. Millä saisimme kaikki työssä olevat miettimään, merkitseekö se jotakin, että koulutamme ihmisiä yhä vähemmän suomalaiseen työyhteisöön ja yhä enemmän tietyn yleismaailmallisen koneen käyttäjiksi tai tietyn ylikansallisen yhtymän palvelukseen. Muutos on taas kerran lähdettävä aikuiskouluttajista. Heille on annettava nykyistä enemmän mahdollisuuksia kokea itse kansainvälistymisen haasteet. Opetusministeriössä onkin pyritty avaamaan myös aikuiskouluttajille samat kansainvälisen opettajainvaihdon ja stipendien mahdollisuudet kuin jo nyt on koulujen opettajilla. Hyvään alkuun onkin jo päästy. Mainittakoon kuitenkin vertailun vuoksi, että opetusministeriö on asettanut tavoitteeksi lähettää 5000 korkeakouluopiskelijaa vuosittain ulkomaiden yliopistoihin.

Aikuiskoulutuksessa olisi entistä tietoisemmin panostettava edellä mainitsemiini kansainvälistymisen välineisiin. Kielissä olisi erityisesti korostettava koulussa vähälle jäävien suurten kielten (venäjä, ranska, saksa, espanja, kiina, japani) osuutta. Samalla on perehdyttävä vieraisiin kulttuureihin.

Kansainvälistymisessä sekä kilpailun että yhteistyön ensimmäinen ja tärkein askel on toisen osapuolen tuntemus.

\section{Koti, uskonto ja Eurooppa?}

Kulttuurin muutokset ovat tulevaisuudessa yhä harvemmin sisäsyntyisiä ja yhä useammin kansainvälisistä innovaatioista ja sopimuksista alkunsa saavia. Me olemme joka päivä entistä kansainvälisempiä. Seuraava sukupuoli työskentelee ajoittain ulkomailla tai ainakin ulkolaisten kanssa.

En pysty kuvittelemaan tämän kehityksen tavoitteeksi ehkä lopputulokseksi mitään yhtenäiskulttuurin omaksunutta euroihmistä, vaikka epäilemättä maailmankansalaiset tulevaisuudessa lisääntyvät. Vaikka kansainvälistyminen johtaakin kansojen lähentymiseen, se ei johda niiden sulautumiseen.

Niille aikuiskasvattajille, jotka pitävät myös edelleen kansallisen identitettimme, juuriemme, sanalla sanoen suomalaisuuden säilyttämistä tärkeänä, muodostuu tästä kansainvälistyvässä maaimassa yhä haasteellisempi tehtävä. 
Ensi vuosituhannella siirtolaisuusongelmat ja siitä johtuvat monenlaiset kansallisen identiteeettimme kriisit ovat meidänkin arkipäiväämme. Niissä oloissa kansankulttuurin säilyttäminen ja kehittäminen tulee olemaan sivistystyölle todella haasteellinen tehtävä.
Emme me kertaheitolla muutu eurooppalaisiksi. Askeleet ovat pieniä, mutta sitä nopeammin niitä on ryhdyttävä ottamaan. Siispä edellä esitetyn pohjalta, mutta nyt tietoisesti: entistä kiivaammin saksan vahvojen verbien kimppuun. Siitäkin se voi alkaa. 